\title{
Minimum Wages, Morality, and Efficiency: A Choice Experiment
}

Conor Lennon, Jose Fernandez, Stephan Gohmann, and Keith Teltser

\author{
Online Appendix
}

\section{A Experiment/Survey Document}

\section{A.1 Sample Survey}

This appendix section contains a complete survey, beginning on the following page. A.1

\footnotetext{
A.1 The survey remains available to examine and complete at http://louisville.az1.qualtrics.com/jfe/form/SV 39Keupyg3Vnqt49.
} 
English

Minimum Wages, Morality, and Efficiency: A choice Experiment

September, 2018

Dear Survey Participant:

You are invited to participate in a research study about attitudes toward minimum wages. This study is conducted by Dr. Stephan Gohmann, Dr. Keith Teltser, Dr. Conor Lennon, and Dr. Jose Fernandez of the University of Louisville. There are no known risks for your participation in this research study. The information collected may not benefit you directly. The information learned in this study may be helpful to others. The information you provide will be used to help us understand the nature of public preferences towards minimum wages. Your completed survey will be stored at the University of Louisville. The survey will take approximately 10 to 12 minutes to complete. Payment will be $\$ 1$ for completing the survey. You will also be asked if you would be willing to be re-contacted for a similar follow-up survey. If you are re-contacted, you will also be compensated $\$ 1$ for that follow-up survey.

Individuals from the Department of Economics at the University of Louisville, the Institutional Review Board (IRB), the Human Subjects Protection Program Office (HSPPO), and other regulatory agencies may inspect these records. In all other respects, however, the data will be held in confidence to the extent permitted by law. Should the data be published, your identity will not be disclosed. 
Taking part in this study is voluntary. By answering survey questions you agree to take part in this research study. You do not have to answer any questions that make you uncomfortable. You may choose not to take part at all. If you decide to be in this study you may stop taking part at any time. If you decide not to be in this study or if you stop taking part at any time, you will not lose any benefits for which you may qualify.

If you have any questions, concerns, or complaints about the research study, please contact: Dr. Conor Lennon (phone: (502) 852-7773; e-mail: conor.lennon@louisville.edu) or Dr. Jose Fernandez (phone: (502) 852-4861; email: jose.fernandez@louisville.edu).

If you have any questions about your rights as a research subject, you may call the Human Subjects Protection Program Office at (502) 852-5188. You can discuss any questions about your rights as a research subject, in private, with a member of the Institutional Review Board (IRB). You may also call this number if you have other questions about the research, and you cannot reach the research staff, or want to talk to someone else. The IRB is an independent committee made up of people from the University community, staff of the institutions, as well as people from the community not connected with these institutions. The IRB has reviewed this research study.

If you have concerns or complaints about the research or research staff and you do not wish to give your name, you may call $1-877-852-1167$. This is a 24 hour hot line answered by people who do not work at the University of Louisville.

Please note that this survey will be best displayed on a laptop or desktop computer. Some features may be less compatible for use on a mobile device. If 
you do not wish to participate in this study, please close this window now and your session will end.

Sincerely,

Dr. Conor J. Lennon

Dr. Jose M. Fernandez

I consent, begin the study

I do not consent, I do not wish to participate, please delete all record of my involvement. 
You will be able to continue with the survey after reading the brief text below.

The Fair Labor Standards Act explains that, as of June 2018, the federal minimum wage in the United States is $\$ 7.25$ per hour of work. It is a federal crime to employ workers at any hourly wage below the federal minimum wage. Individual states are free to set a higher minimum wage, but the federal rate is the lowest possible hourly wage (there are some exceptions such as the hospitality industry, where tipping is customary).

In March of 2018, the Bureau of Labor Statistics reported that 1.8 million hourly workers, roughly 2.3 percent of all hourly workers, were paid no more than the federal minimum wage. Of those 1.8 million workers;

- 49 percent were between 16 and 24 years old.

. 65 percent work part-time.

- 53 percent have a high school diploma or less.

- 17 percent are Black, and 17 percent are Hispanic or Latino.

. 58 percent are female.

In recent years, there has been discussion about raising the federal minimum wage. Those in favor of an increase see the minimum wage as a potential way to reduce poverty and inequality. Opponents note that increasing the minimum wage could lead to unemployment because employers will not be able to afford to employ as many workers. 
In this study, you may be asked to consider the minimum wage compared to some alternative policy options. We will refer to your options as System A and System B in each scenario. The order of presentation is randomly chosen. For that reason, you may be asked to consider System B prior to considering System A. You will be asked to express your opinion on the ethics of these systems, including if you feel they are fair (to both workers and their potential employers), dignified, or exploitative. You will then be given some potential associated employment outcomes to consider and asked to "vote" on a preferred option.

Based on the findings of this study, we will prepare and submit a summary of our findings (in the form of an op-ed) to major national newspapers including the New York Times, the Washington Post, the Chicago Tribune, and the Los Angeles Times. We may also be asked to speak about our findings on television, radio, or at public speaking events. In order to help us explain how American people view the minimum wage, we ask that you commit to answering our study's questions honestly.

Note that all of the answers that you provide will remain anonymous and treated with absolute confidentiality. The researchers do not know your identity, and they will never be able to match your name with the answers that you provide.

Do you commit to carefully reading and providing your thoughtful and honest answers to the questions in this survey?

I commit to answering the questions in this study honestly and truthfully.

I do not commit to answering the questions in this study honestly and truthfully, please remove me from this study. 
System A: This system features a minimum wage of $\$ 10.10$ per hour worked. This minimum applies in all 50 US states and employers must pay their employees at least $\$ 10.10$ per hour. Any employer who pays any worker a wage below $\$ 10.10$ would be guilty of a federal crime under the Fair Labor Standards Act.

Please consider the following statements and indicate your agreement or disagreement with them by moving the appropriate slider.

Note: the definition of underlined words can be viewed by hovering over them with the mouse cursor.

This system exploits workers

Strongly

disagree Somewhat disagree

0
Neither agree nor disagree

50
Somewhat agree

75
Strongly

agree

This system is unfair to workers 
Strongly

disagree Somewhat disagree

0
Neither agree nor disagree

50

$\underset{75}{\text { Somewhat agree }}$

Strongly

agree

This system is unfair to employers

Strongly

disagree Somewhat disagree

$0 \quad 25$
Neither agree nor disagree

50
Somewhat agree 75
Strongly

agree

This system does not respect human dignity.

Strongly

disagree Somewhat disagree

$$
0
$$$$
25
$$

Neither agree nor disagree

$\underset{75}{\text { Somewhat agree }}$

Strongly

agree 
This system conflicts with my personal values

Strongly

disagree Somewhat disagree

0

25

O
Neither agree nor disagree

50

Somewhat agree

75

Strongly

agree 
System B: the federal government abolishes all minimum wages. For the purposes of this survey, please assume that this law would apply equally in all 50 US states and would override existing laws in all states. That is, there would be no minimum wage law anywhere in the United States. Workers and employers would negotiate hourly wages on a case-by-case and person-by-person basis. All wage agreements that workers and employers agree to are completely legal.

Please consider the following statements and indicate your agreement or disagreement with them by moving the appropriate slider.

Note: the definition of underlined words can be viewed by hovering over them with the mouse cursor.

This system exploits workers

Strongly

disagree Somewhat disagree

0
Neither agree nor disagree

50
Somewhat agree

75
Strongly

agree 
This system is unfair to workers

$\begin{array}{lcccr}\text { Strongly } & \text { Neither agree nor } & \text { Strongly } \\ \text { disagree } & \text { Somewhat disagree } & \text { disagree } & \text { Somewhat agree } & \text { agree } \\ 0 & 25 & 50 & 75 & 100\end{array}$

O

This system is unfair to employers
Strongly
Neither agree nor
disagree Somewhat disagree
disagree
50
$\underset{75}{\text { Somewhat agree }}$
Strongly
agree
100

This system does not respect human dignity.

$\begin{array}{lcccr}\text { Strongly } & & \text { Neither agree nor } & & \text { Strongly } \\ \text { disagree } & \text { Somewhat disagree } & \text { disagree } & \text { Somewhat agree } & \text { agree } \\ 0 & 25 & 50 & 75 & 100\end{array}$


This system conflicts with my personal values

Strongly

disagree Somewhat disagree

0

25

O
Neither agree nor disagree

50

Somewhat agree

75

Strongly

agree 
In this part of the survey, you will consider some potential consequences of the systems you have rated. You will be presented with three choice scenarios. This is the first scenario.

For the purposes of the survey consider the potential effect of the alternative systems on a small U.S. city. The city contains 100,000 adults who are willing and able to work. Of these $100,000,55,000$ are male and 45,000 are female. In addition, 60,000 are White, 20,000 are Black, and 20,000 are Hispanic/Latino.

The table below summarizes what happens to employment in the city under each alternative system.

\begin{tabular}{|c|c|c|}
\hline System A & System B \\
\hline $\begin{array}{c}\text { Minimum wage of \$10.10 } \\
\text { find work: } 10,000\end{array}$ & Minimum Wage Eliminated \\
$\begin{array}{c}\text { Number of people unable to } \\
\text { find work: } \mathbf{8 , 0 0 0}\end{array}$ \\
\hline $\begin{array}{c}\text { For System A, among the workers who are unable to find work, } 40 \\
\text { percent are members of a minority community (they are Black or } \\
\text { Hispanic) and } \mathbf{4 5} \text { percent are female. }\end{array}$
\end{tabular}


For System B, among the workers who are unable to find work, 40 percent are members of a minority community and 45 percent are female.

Please indicate the system you would like to see implemented by choosing one of the options below. Please think of your selection as the expression of a "vote."

System A

System B

On a scale of 0 to 100 , how would you rate the overall desirability of each system?

\begin{tabular}{|c|c|c|c|c|}
\hline $\begin{array}{l}\text { Extremely } \\
\text { undesirable } \\
0\end{array}$ & $\begin{array}{c}\text { Somewhat } \\
\text { undesirable } \\
25\end{array}$ & $\begin{array}{c}\text { Neither desirable } \\
\text { nor undesirable } \\
50\end{array}$ & $\begin{array}{c}\text { Somewhat } \\
\text { desirable } \\
75\end{array}$ & $\begin{array}{r}\text { Extremely } \\
\text { desirable } \\
100\end{array}$ \\
\hline
\end{tabular}

System A

O

System B 
This is the second scenario.

Again, consider the potential effect of the alternative systems on a small U.S. city. The city contains 100,000 adults who are willing and able to work. Of these $100,000,55,000$ are male and 45,000 are female. In addition, 60,000 are White, 20,000 are Black, and 20,000 are Hispanic/Latino.

The table below summarizes what happens to employment in the city under each system.

\begin{tabular}{|c|c|}
\hline System A & System B \\
\hline Minimum wage of $\$ 10.10$ & Minimum Wage Eliminated \\
\hline $\begin{array}{l}\text { Number of people unable to } \\
\text { find work: } 10,000\end{array}$ & $\begin{array}{l}\text { Number of people unable to } \\
\text { find work: } 6,000\end{array}$ \\
\hline \multicolumn{2}{|c|}{$\begin{array}{l}\text { For System A, among the workers who are unable to find work, } 40 \\
\text { percent are members of a minority community (they are Black or } \\
\text { Hispanic) and } 45 \text { percent are female. }\end{array}$} \\
\hline \multicolumn{2}{|c|}{$\begin{array}{l}\text { For System B, among the workers who are unable to find work, } 40 \\
\text { percent are members of a minority community and } 45 \text { percent are }\end{array}$} \\
\hline
\end{tabular}


female.

Please indicate the system you would like to see implemented by choosing one of the options below. Please think of your selection as the expression of a "vote."

\section{System A}

System B

On a scale of 0 to 100 , how would you rate the overall desirability of each system?

$\begin{array}{lcccr}\begin{array}{l}\text { Extremely } \\ \text { undesirable } \\ 0\end{array} & \begin{array}{c}\text { Somewhat } \\ \text { undesirable } \\ 25\end{array} & \begin{array}{c}\text { Neither desirable } \\ \text { nor undesirable }\end{array} & \begin{array}{c}\text { Somewhat } \\ \text { desirable } \\ 75\end{array} & \begin{array}{r}\text { Extremely } \\ \text { desirable } \\ 100\end{array} \\ \text { System A } & & & & \\ 0 & & & \\ 0 & & & \end{array}$

System B

0

0 
This is the third scenario.

For the purposes of the survey consider the potential effect of the alternative systems on a small U.S. city. The city contains 100,000 adults who are willing and able to work. Of these 100,000 people, 55,000 are male and 45,000 are female. In addition, 60,000 are White, 20,000 are Black, and 20,000 are Hispanic/Latino.

The table below summarizes what happens to employment in the city under each system.

\begin{tabular}{|c|c|c|}
\hline System A & System B \\
\hline Minimum wage of \$10.10 & Minimum Wage Eliminated \\
\begin{tabular}{|l} 
Number of people unable to \\
find work: 10,000
\end{tabular} & $\begin{array}{c}\text { Number of people unable to } \\
\text { find work: } 4,000\end{array}$ \\
\hline $\begin{array}{c}\text { For System A, among the workers who are unable to find work, } 40 \\
\text { percent are members of a minority community (they are Black or } \\
\text { Hispanic) and } 45 \text { percent are female. }\end{array}$ \\
$\begin{array}{c}\text { For System B, among the workers who are unable to find work, } 40 \\
\text { percent are members of a minority community and } 45 \text { percent are }\end{array}$
\end{tabular}


female.

Please indicate the system you would like to see implemented by choosing one of the options below. Please think of your selection as the expression of a "vote."

System A

System B

On a scale of 0 to 100 , how would you rate the overall desirability of each system?

\section{Extremely} undesirable

0

System A

O

System B
Neither desirable

nor undesirable

50
Somewhat desirable

75
Extremely desirable undesirable

25 
This is the third scenario.

For the purposes of the survey consider the potential effect of the alternative systems on a small U.S. city. The city contains 100,000 adults who are willing and able to work. Of these 100,000 people, 55,000 are male and 45,000 are female. In addition, 60,000 are White, 20,000 are Black, and 20,000 are Hispanic/Latino.

The table below summarizes what happens to employment in the city under each system.

\begin{tabular}{|c|c|c|}
\hline System A & System B \\
\hline Minimum wage of \$10.10 & Minimum Wage Eliminated \\
\begin{tabular}{|l} 
Number of people unable to \\
find work: 10,000
\end{tabular} & $\begin{array}{c}\text { Number of people unable to } \\
\text { find work: } 2,000\end{array}$ \\
\hline $\begin{array}{c}\text { For System A, among the workers who are unable to find work, } 40 \\
\text { percent are members of a minority community (they are Black or } \\
\text { Hispanic) and } 45 \text { percent are female. }\end{array}$ \\
$\begin{array}{c}\text { For System B, among the workers who are unable to find work, } 40 \\
\text { percent are members of a minority community and } 45 \text { percent are }\end{array}$
\end{tabular}


female.

Please indicate the system you would like to see implemented by choosing one of the options below. Please think of your selection as the expression of a "vote."

System A

System B

On a scale of 0 to 100 , how would you rate the overall desirability of each system?

\section{Extremely} undesirable 0

System A<smiles>[O]</smiles>

System B

Somewhat
undesirable
25

Neither desirable

nor undesirable 50
Somewhat desirable 75
Extremely desirable 


\section{English}

The following question asks you to recall the choices you made.

Please check all of the below sentences that apply to your choices, as truthfully and honestly as possible.

I chose System A (a minimum wage of \$10.10) in at least one choice opportunity I chose System B (no minimum wage) in at least one choice opportunity 


\section{English}

Again, please consider the choices you made.

Please check all of the below sentences that apply to your choices, as truthfully and honestly as possible.

I would have never chosen System A (a minimum wage of

$\$ 10.10$ ) regardless of the number of workers who were able to find work

I would have never chosen System B (no minimum wage) regardless of the number of workers who were able to find work

None of the above 


\section{English}

Suppose 10,000 people were unable to find work under System A (minimum wage of $\$ 10.10)$. Please use the slider below to select a numerical answer to complete the missing part of the following statement: I would be willing to choose System B (no minimum wage) instead of System A if the number of people unable to find work was less than

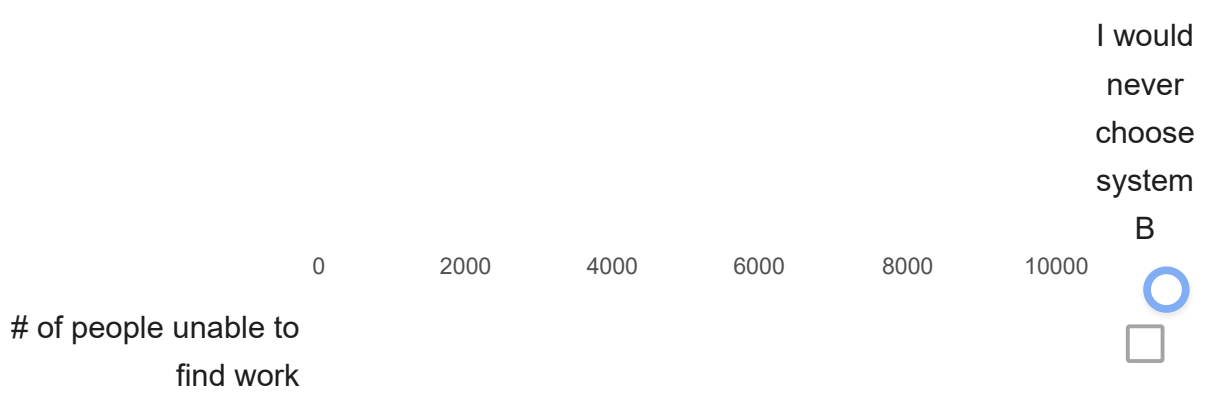


As mentioned earlier, we will share the findings of this study with the general public and policy makers by sending them to major national newspapers for publication as an op-ed.

To what extent do you believe that policy makers will take your opinion about the minimum wage into consideration?

Not at all

Very little

Little

Somewhat

Very much

To what extent do you believe that policy makers should take your opinion into consideration?

Not at all

Very little

Little

Somewhat

Very much 
In this section of the survey we ask that you provide some sociodemographic information.

Thank you for helping us collect accurate information.

What is your age?

Are you...

Male

Female

In which state do you currently reside? 
Which statement best describes your current employment status?

Working (paid employee)

Working (self-employed)

Not working (disabled)

Not working (temporary layoff from a job)

Not working (retired)

Not working (looking for work)

Not working (other)

Prefer not to answer

Prefer not to answer

What is the highest level of school you have completed or the highest degree you have received?

Less than high school degree

High school graduate (high school diploma or equivalent including GED)

Some college but no degree

Associate degree in college (2-year)

Bachelor's degree in college (4-year)

Master's degree

Doctoral degree 
Professional degree (JD, MD)

Information about income is very important to understand. Please indicate the answer that includes your entire household income in 2017 before taxes.

Less than $\$ 10,000$

$\$ 10,000$ to $\$ 19,999$

$\$ 20,000$ to $\$ 29,999$

$\$ 30,000$ to $\$ 39,999$

$\$ 40,000$ to $\$ 49,999$

$\$ 50,000$ to $\$ 59,999$

$\$ 60,000$ to $\$ 69,999$

$\$ 70,000$ to $\$ 79,999$

$\$ 80,000$ to $\$ 89,999$

$\$ 90,000$ to $\$ 99,999$

$\$ 100,000$ or more

Prefer not to answer

To which racial group do you most identify?

White

Asian 
Black or African American

American Indian or Alaska Native
Native Hawaiian or Pacific Islander

Other

Here is a 5-point scale on which the political views that people might hold are arranged from more liberal (left) to more conservative (right).

Where would you place yourself on this scale?

More Liberal

1 2

Political Ideology
More Conservative

3

( 4
5

What is your religious affiliation?

Athiest/Agnostic

Christianity

Judaism

Islam 
My affiliation is not listed

No religious affiliation

Have you donated money to or volunteered for a non-profit or charitable organization in the past 2 years?

Yes

No

Do you think of yourself as closer to the Republican or Democratic Party?

Republican

Democratic

Neither

Have you ever worked in a position where your hourly wage was equal to the minimum wage?

Yes, my current job pays minimum wage.

Yes, a previous job paid minimum wage.

No 
Is any member of your immediate family currently working in a position that pays minimum wage?
Yes
No
Unsure

Powered by Qualtrics 


\section{English}

Please indicate your level of agreement with the following sentence:

Some aspects of human life are sacred and should never be violated regardless of the possible material gains.

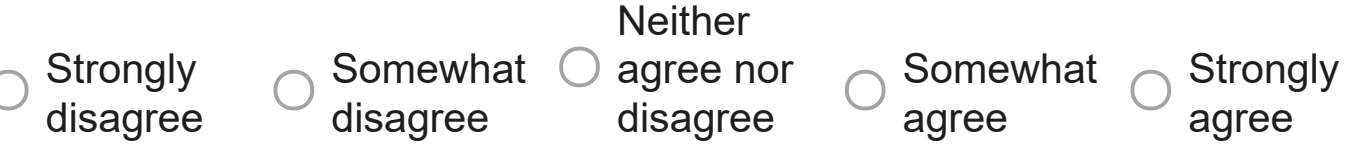

Please indicate your level of agreement with the following sentence:

Allowing people to experience suffering in order to maintain an ethical principle is morally wrong.

Strongly
disagree $\begin{aligned} & \text { Somewhat } \\ & \text { disagree }\end{aligned} \quad \begin{aligned} & \text { Neither } \\ & \text { agree nor } \\ & \text { disagree }\end{aligned} \bigcirc \begin{aligned} & \text { Somewhat } \\ & \text { agree }\end{aligned} \bigcirc \begin{aligned} & \text { Strongly } \\ & \text { agree }\end{aligned}$


Please indicate your level of agreement with the following sentence:

\section{People should have the freedom to do things that offend others' morals so long as no one is directly physically or financially harmed.}

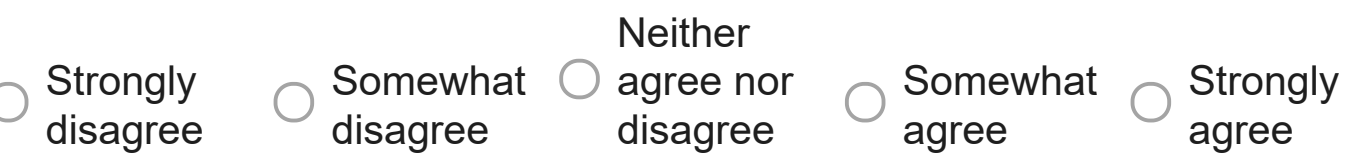

Consider the following scenario:

Suppose a viral epidemic is killing millions of people around the world. The virus is fatal in every case: once someone contracts the virus they cannot be saved but the virus takes several days to kill a person. A doctor has developed two substances. One is a vaccine and the other is a deadly poison. Due to a clerical error, the doctor is not sure which is which. The doctor is taking care of two patients who have the fatal virus.

The only way to identify the vaccine is to inject each patient with one of the two substances. If the doctor injects the substances one of the patients will die immediately from the poison. However, because the doctor will know which substance is the vaccine, millions of other lives will be saved.

Please indicate your level of agreement with the following sentence: 
The doctor should inject the substances into the patients.

$\bigcirc \begin{aligned} & \text { Strongly } \\ & \text { disagree }\end{aligned} \begin{aligned} & \text { Somewhat } \\ & \text { disagree }\end{aligned} \quad \begin{aligned} & \text { Neither } \\ & \text { agree nor } \\ & \text { disagree }\end{aligned} \bigcirc \begin{aligned} & \text { Somewhat } \\ & \text { agree }\end{aligned} \bigcirc \begin{aligned} & \text { Strongly } \\ & \text { agree }\end{aligned}$


We are planning to contact some of the respondents to this survey sometime in the next 4 to 6 weeks to complete a similar type of survey. If you are interested in being contacted, please indicate below. If you are recontacted and choose to participate, your participation will be compensated.

Yes, I am willing to be contacted again
No, I am not willing to be contacted again.

If you have any feedback on our survey (typos, errors, general comments, and so on) please let us know. You can type your comments into the text box below. 
Thank you for completing our survey. Your response has been recorded.

Your MTurk completion code is: 1234567890

Please copy and paste the completion code into the space provided in the mTurk HIT to ensure your prompt payment.

Powered by Qualtrics 


\section{B Practical Experimental Details}

This appendix describes participant recruitment, pre-testing, payments and earnings, time taken, along with the results of various checks on participants' attention.

\section{B.1 Recruitment}

We recruited participants using Amazon's mTurk platform. On this platform, "requesters” pay "turkers" to perform relatively short human intelligence tasks (HITs). These tasks include data entry, audio transcription, and so on. In addition, the platform is used for marketing surveys and experiments.

\section{B.2 Pre-testing}

We completed a round of pretesting in August of 2018. To be precise, we did two pretests, one involved gathering and paying for 50 responses to check our survey instrument was working as intended. Then, we gathered 250 responses to estimate the effect size of interest and to understand if the parameters would generate enough variation in the data. The pretest data is not presented anywhere in the paper.

In the pretests, we allowed the unemployment rate to vary randomly in System A between $4 \%$, $6 \%, 8 \%$ and $10 \%$. For System B, the rate varied between $4 \%$ and $6 \%$ (presented to participants as X out of 100,000 who want to work are unable to find a job). We gave participants three choice scenarios with the unemployment rate randomly drawn for each system. From this, we found that in order to overcome the mean repugnance between A and B, respondents needed about a 5,000 (5 percentage point) difference in employment. For that reason, about 15\% of our respondents in the pretest faced three choice scenarios where all three were redundant either the unemployment rate in system B was the same or worse than A. That is, due to the

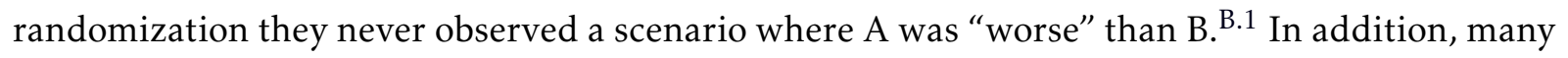
experimental participants observed situations where unemployment in System B was always significantly lower than System A.

\footnotetext{
B.1 There are eight possible pairings, the unemployment rate in system B was the same or worse than A in three of these eight pairings.
} 
To avoid these extremes, we altered the survey design to set System A's unemployment level at either $8 \%(8,000$ out of 100,000 workers $)$ or $10 \%$ upon entering the survey. We then asked the respondent to compare System A to System B in four scenarios. In the first scenario, the unemployment rate for System B was $8 \%$, in the second it was $6 \%$, in the third it was $4 \%$, and $2 \%$ in the final scenario. This ensured participants saw both a situation where the unemployment difference between System A and B was small and one where it was not.

\section{B.3 Earnings and Time Taken}

The average respondent took just over 12 minutes to complete the survey. The median respondent took 10 and a half minutes. Each respondent was paid $\$ 1$. The average time is inflated significantly by outliers in the right tail of the "time taken" distribution. For example, one respondent took over 2 hours and 40 minutes to complete the survey. It is likely that this person did not spend that time focused on the survey. Indeed, given $25 \%$ of reliable survey respondents took less than 8 minutes to do the survey, we suspect that the time taken to do the survey is artificially inflated for reasons that are unrelated to the survey's length (such as working on other short mTurk tasks or due to interruptions from phone calls, social media, bathroom breaks, and so on). Lastly, dropping those above the 95th percentile of the time distribution (a survey completion time of about 26 minutes) brings the median time to completion to 10 minutes and 7 seconds and the mean to 10 minutes and 55 seconds.

\section{B.4 Attention Checks}

There are several attention checks built into the survey. We consider two of these to be relatively strong and three of them to be somewhat weaker. The stronger checks ask respondents (1) to recall if they ever chose each system and (2) if they would never choose either of the systems. They fail the first check if they cannot accurately recall if they chose System A or B across the various choice scenarios. They fail the second check if they claim they would never choose one of the systems but actually did choose that system in at least one choice scenario. We eliminate anyone who fails both of these strong checks from our sample. Table B.1 reports on the "pass" and "fail" rates in the various attention checks for the remaining 2,219 responses. 
Table B.1: Checks on Attention and Reliability

\begin{tabular}{|c|c|c|c|}
\hline $\begin{array}{l}\text { Reliability } \\
\text { Check }\end{array}$ & Description & Pass & Fail \\
\hline \multirow[t]{2}{*}{1} & Cannot recall own choices & 2,035 & 184 \\
\hline & & $91.7 \%$ & $8.3 \%$ \\
\hline \multirow[t]{2}{*}{2} & $\begin{array}{c}\text { Claims they would never choose a system which they did } \\
\text { choose }\end{array}$ & 2,033 & 186 \\
\hline & & $91.6 \%$ & $8.4 \%$ \\
\hline \multirow[t]{2}{*}{3} & Choices Correspond to Desirability Rating of each system & 1,656 & 563 \\
\hline & & $74.6 \%$ & $25.4 \%$ \\
\hline \multirow[t]{2}{*}{4} & $\begin{array}{l}\text { Suggested they would choose System B for some level of } \\
\text { employment but did not do so in the experiment }\end{array}$ & 2,135 & 84 \\
\hline & & $96.2 \%$ & $3.8 \%$ \\
\hline \multirow[t]{2}{*}{5} & Choices reflect monotonic preferences & 2,139 & 80 \\
\hline & & $96.4 \%$ & $3.6 \%$ \\
\hline
\end{tabular}

\footnotetext{
The table reports how many respondents passed or failed five checks on attention, response reliability, and consistency. Statistics are reported for 2,219 respondents. This total excludes those who failed both the first and second reliability checks listed above plus those who appear to have taken the survey more than once based on their IP address.
}

Participants' performance on the stronger attention checks are presented as the first two entries in the table. Among those who did not fail both of those reliability checks, there remains a small minority who failed one of them. However we keep these responses in our data because many of those who fail only one of the strong checks do not fail any of the other weaker three tests. In any case, the estimates presented in the paper are almost identical if we exclude those who fail just one of those strong checks. Indeed, including those who fail both of our stronger checks does little to alter the estimates.

The third reliability check in the table examines if participants chose the system they rated as most "desirable." Given the loaded and subjective meaning of that term, we do not consider "failing" this check to be a major concern. A person could consider System A as "most desirable" but chooses System B due to its employment consequences.

Reliability check number four examines respondents' answers to our "switching" question. In the survey, towards the end, our "switching" question asks respondents to choose (on a 
sliding scale) the level of unemployment that would be required to get them to switch from System A (the level of unemployment for A was fixed for a given respondent but varied across respondents between 8,000 and 10,000). A respondent fails this check if they choose some number in this question that implies that they should have chosen System B in the survey but did not. The data shows that $96.2 \%$ of respondents passed this test.

The fifth reliability check examines inconsistent preferences. There are four binary choices for each participant, leading to 16 combinations of choices. Eight of these 16 potential routes through the experiment reflect consistent preferences in the sense that the participant always answers the same choice in each scenario or switches from System A or B to the other, only once. A respondent therefore fails this check if their responses do not respect monotonicity. For instance, a respondent who chooses $\mathrm{A}$, then $\mathrm{B}$, then $\mathrm{A}$ again is potentially unreliable. The data shows that $96.4 \%$ of respondents' sets of choices respect monotonicity. 
Table C.1: Logit Estimates

\begin{tabular}{|c|c|c|c|c|c|}
\hline & $\begin{array}{c}(1) \\
\mathrm{P}(\text { Chose A })\end{array}$ & $\begin{array}{c}(2) \\
\mathrm{P}(\text { Chose } \mathrm{A})\end{array}$ & $\begin{array}{c}(3) \\
\mathrm{P}(\text { Chose A })\end{array}$ & $\begin{array}{c}(4) \\
\mathrm{P}(\text { Chose A })\end{array}$ & $\begin{array}{c}(5) \\
\mathrm{P}(\text { Chose A) }\end{array}$ \\
\hline Difference in Unemployment Rate & $\begin{array}{l}-0.0402^{* * *} \\
(0.00188)\end{array}$ & $\begin{array}{c}-0.0426^{* * *} \\
(0.00162)\end{array}$ & $\begin{array}{c}-0.0400^{* * *} \\
(0.00186)\end{array}$ & $\begin{array}{c}-0.0403^{* * *} \\
(0.00185)\end{array}$ & $\begin{array}{c}-0.0425^{* * *} \\
(0.00160)\end{array}$ \\
\hline Difference in Repugnance & $\begin{array}{l}-0.00431^{* * *} \\
(0.000180)\end{array}$ & $\begin{array}{l}-0.00431^{* * *} \\
(0.000179)\end{array}$ & $\begin{array}{l}-0.00456^{* * *} \\
(0.000188)\end{array}$ & $\begin{array}{l}-0.00434^{* * *} \\
(0.000178)\end{array}$ & $\begin{array}{c}-0.00461^{* * *} \\
(0.000186)\end{array}$ \\
\hline System $A=10,000$ & & $\begin{array}{l}0.0298^{*} \\
(0.0171)\end{array}$ & & & $\begin{array}{l}0.0312^{*} \\
(0.0168)\end{array}$ \\
\hline Min Wage Observed $=\$ 10.10$ & & & $\begin{array}{l}-0.0301 \\
(0.0240)\end{array}$ & & $\begin{array}{l}-0.0367 \\
(0.0227)\end{array}$ \\
\hline Min Wage Observed $=\$ 15$ & & & $\begin{array}{l}-0.112^{* * *} \\
(0.0241)\end{array}$ & & $\begin{array}{l}-0.112^{* * *} \\
(0.0230)\end{array}$ \\
\hline Equal Race and Gender Effects & & & & $\begin{array}{c}0.0102 \\
(0.0224)\end{array}$ & $\begin{array}{c}0.0141 \\
(0.0221)\end{array}$ \\
\hline Unequal Race and Gender Effects & & & & $\begin{array}{c}-0.118^{\star * *} \\
(0.0190)\end{array}$ & $\begin{array}{c}-0.115^{* * *} \\
(0.0189)\end{array}$ \\
\hline No. of Choices & 8,492 & 8,492 & 8,492 & 8,492 & 8,492 \\
\hline No. of Respondents & 2,123 & 2,123 & 2,123 & 2,123 & 2,123 \\
\hline
\end{tabular}

${ }^{* * *}$ Significant at the $1 \%$ level; ${ }^{*}$ Significant at the $5 \%$ level; ${ }^{*}$ Significant at the $1 \%$ level. Standard errors are clustered at the respondent level.

\section{Logit Estimates}

A linear probability model allows us to easily present our data and findings. For completeness, Table C.1 reports post-estimation marginal effects from a binomial logit estimation. In the estimating equation, the variables are the same as in Section 4 of the main body of the paper but $\epsilon_{i c}$ takes on a logit distribution. Note that the outcome variable is 0 or 1 (where choosing System $A=1)$. In each column, we re-estimate the corresponding specification from Table 1 in the body of the paper but, for the sake of brevity, we do not report as many of the coefficients.

The reported coefficients should be multiplied by 100 to be interpreted as percentage point changes. That is, in the first column, a one percentage point difference in the unemployment rate between the two systems is associated with a 4.02 percentage point reduction in the probability of choosing System A. In each specification, the estimates are remarkably similar to the main estimates in the body of the paper. 


\section{System Ratings on Several Dimensions \\ $100=$ Strongly Agree}
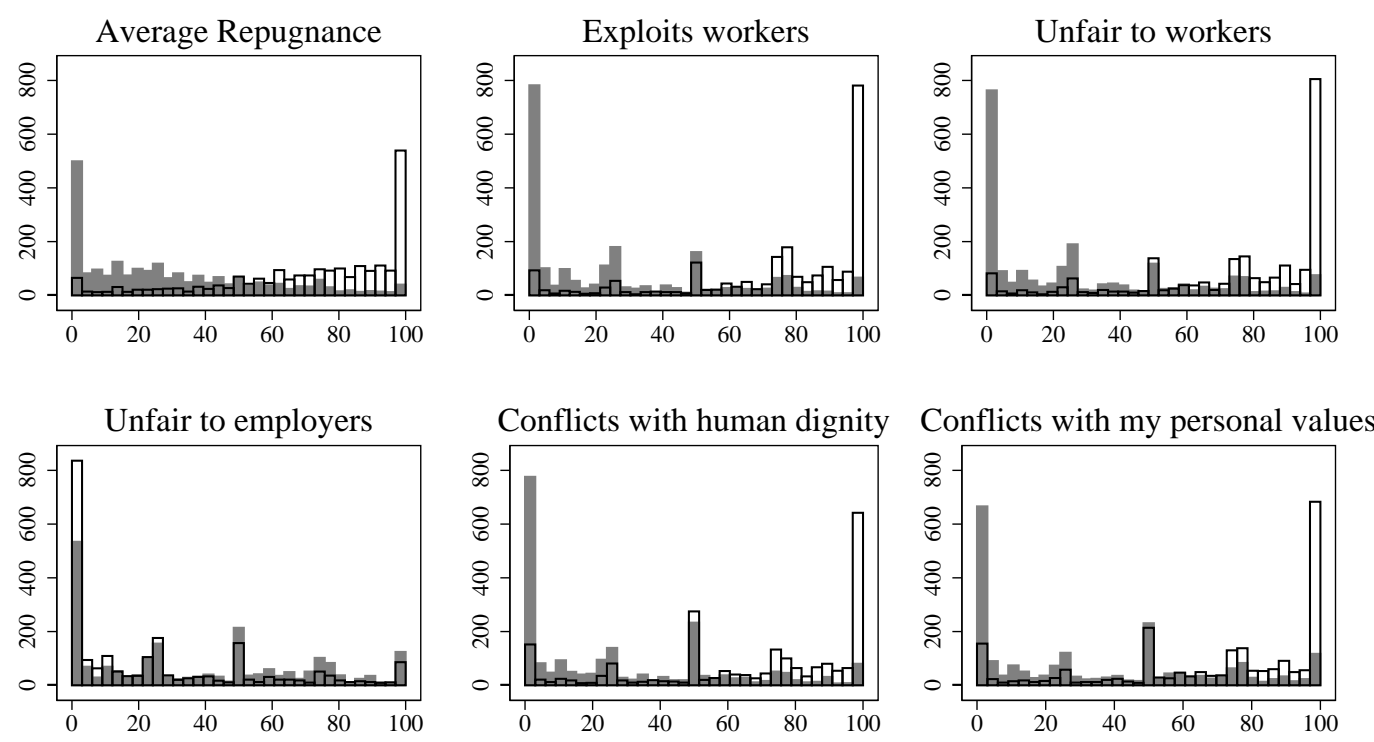

\section{System A}

System B

Figure D.1: Ratings of System A (minimum wage of $\$ \mathrm{X}$ ) and System B (no minimum wage) on Moral Dimensions.

\section{Additional Sample Characteristics}

\section{D.1 Repugnance Ratings}

Figure D.1 illustrates the rating of each system on the five dimensions of morality described earlier. As a reminder, each respondent rated each aspect of each system on a scale from zero to 100. The order in which respondents viewed the two alternative systems was randomized. D.1 A clear pattern can be seen. For the exploitation, unfairness to workers, human dignity, and personal values morality questions System B (no minimum wage) was viewed less favorably than System A (minimum wage of \$X). For example, just under 800 of the 2,219 respondents viewed System A as completely fair and not exploitative (these respondents stated "strongly disagree" with the statements "[T]his system is unfair to workers" and "[T]his system exploits

\footnotetext{
D.1 Unfortunately, we did not set the Qualtrics system to record the order of presentation for this randomization.
} 
workers"). In contrast, about the same number of respondents viewed System B as maximally unfair and exploitative. The exception to this pattern is in the "unfair to employers" question. There, the two systems were not viewed much differently: the distribution of responses to the question suggests System B was perhaps viewed as a little fairer to employers. For that reason, the "average repugnance" score is generated as the average of the exploitation, unfairness to workers, human dignity, and personal values morality questions. Estimates which use any one (rather than the average) of these four measures of moral concerns produce very similar findings. In addition, including "unfairness to employers" in the measure of average repugnance changes little. If anything, because it brings the "averages" slightly closer together, it increases the sensitivity of our estimates to differences in repugnance ratings. See Appendix D for a complete breakdown of how each system was viewed, particularly as a function of the minimum wage observed $(\$ 7.25, \$ 10.10$, or $\$ 15)$ and self-reported political party affiliation.

\section{D.2 Geographic Representation}

Figure D.2 illustrates the ratio between the percent of all responses from a given state in our sample relative to that state's share of the U.S. population in 2017 as reported by the Census Bureau. Most states are reasonably represented but states such as Oregon and Delaware are over- and under-represented, respectively. Note that our main findings are robust to excluding any state which was more than $20 \%$ over- or under-represented (that is, omitting any state with a 1.2 to 1 ratio of response share to population share and/or omitting those with a .8 to 1 ratio).

\section{D.3 Detailed Repugnance Ratings}

Table D.1 reports the repugnance ratings for each system. First, it presents ratings for System A as a function of the minimum wage observed. Notice that the ratings of each system are very responsive to minimum wage observed with the system with a $\$ 15$ minimum being markedly less problematic in four of the five moral dimensions. The exception to the pattern is in how higher minimum wages are unfair to employers. These System A ratings should be compared to the ratings for System B (which eliminates the minimum wage). Even a system with a \$7.25 minimum wage is viewed very differently to one with no minimum wage. 


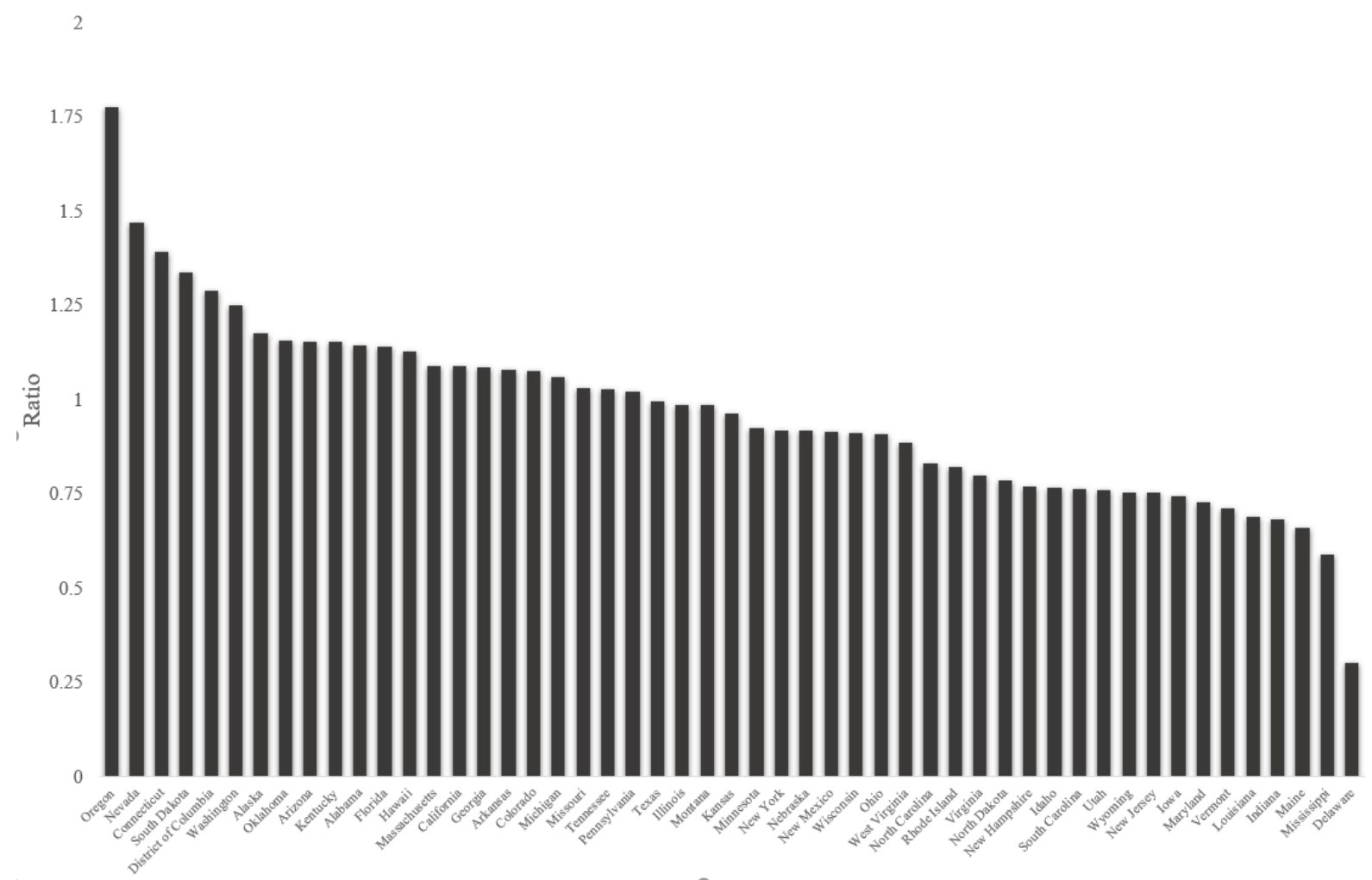

Figure D.2: Ratio of Representation: Experiment Participants vs. U.S. Population

The table then presents the ratings for each system as a function of reported political affiliation. Unsurprisingly, respondents who see themselves as closer to the Democratic Party drive a lot of the difference in ratings between the two systems. However, Republicans also tend to report that System B (relative to System A) is more exploitative, unfair to workers, disrespectful to human dignity, and is in conflict with their personal values. The responses for those who claim to be affiliated with neither party tend to lie between the score for the typical Democrat and Republican respondent. This pattern provides additional confidence in the reliability of our respondents' answers to the survey's demographic questions.

\section{D.4 Do People Believe their Responses Matter?}

In the third stage of the experiment, to examine the degree to which participants believe their responses matter, we remind participants of our intention to heavily publicize our findings and ask respondents if policy makers will be interested in our findings and if they should be 
Table D.1: Detailed Repugnance Ratings

System A

\begin{tabular}{|c|c|c|c|c|c|}
\hline \multirow[b]{2}{*}{ Min Wage } & \multicolumn{4}{|c|}{ System A } & \multirow{2}{*}{$\begin{array}{c}\text { System B } \\
\text { No Min Wage }\end{array}$} \\
\hline & $\$ 7.25$ & $\$ 10.10$ & $\$ 15$ & All & \\
\hline Count & 446 & 880 & 893 & 2,219 & 2,219 \\
\hline Exploits Workers & 49.4 & 26.8 & 16.6 & 27.2 & 75.6 \\
\hline Unfair to Workers & 50.0 & 26.6 & 18.1 & 27.9 & 74.4 \\
\hline Unfair to Employers & 24.9 & 33.2 & 48.5 & 37.6 & 25.1 \\
\hline Fails to Respect Human Dignity & 48.3 & 26.5 & 19.3 & 28.0 & 67.8 \\
\hline Conflicts with Personal Values & 48.8 & 30.4 & 30.7 & 34.2 & 69.5 \\
\hline
\end{tabular}

$\begin{array}{lcccccccc}\text { Political Affiliation } & \text { Democrat } & \text { Republican } & \text { Neither } & \text { All } & \text { Democrat } & \text { Republican } & \text { Neither } & \text { All } \\ \text { Count } & 1,095 & 614 & 510 & 2,219 & 1,095 & 614 & 510 & 2,219 \\ & & & & & & & & \\ & & & & & & & & \\ \text { Exploits Workers } & 26.1 & 27.4 & 29.4 & 27.2 & 82.6 & 64.8 & 73.4 & 75.6 \\ \text { Unfair to Workers } & 26.6 & 28.1 & 30.5 & 27.9 & 83.0 & 62.4 & 74.9 & 74.4 \\ \text { Unfair to Employers } & 29.5 & 52.0 & 37.8 & 37.6 & 23.0 & 28.8 & 25.0 & 25.1 \\ \text { Fails to Respect Human Dignity } & 25.9 & 29.9 & 30.1 & 28.0 & 76.7 & 54.6 & 64.6 & 67.8 \\ \text { Conflicts with Personal Values } & 28.4 & 43.5 & 35.4 & 34.2 & 78.8 & 56.3 & 65.4 & 69.5 \\ & & & & & & & & \end{array}$

Table reports breakdown of repugnance by minimum wage observed and reported political affiliation.

interested in these findings. Figure D.3 provides the breakdown of respondents answers to those questions. It is clear that most respondents do not believe their voice will be heard. However, over $83 \%$ of respondents feel that their voice should be heard. This provides some additional confidence in the reliability and trustworthiness of our survey responses.

\section{D.5 Sample Characteristics by Political Affiliation}

Table D.2 reports on the demographic characteristics we gathered for the 2,219 participants with valid responses. As we have a convenience participant group, they are not representative of the U.S. population. In particular, the table illustrates that the sample was predominantly 
Policymakers Will Consider these Findings

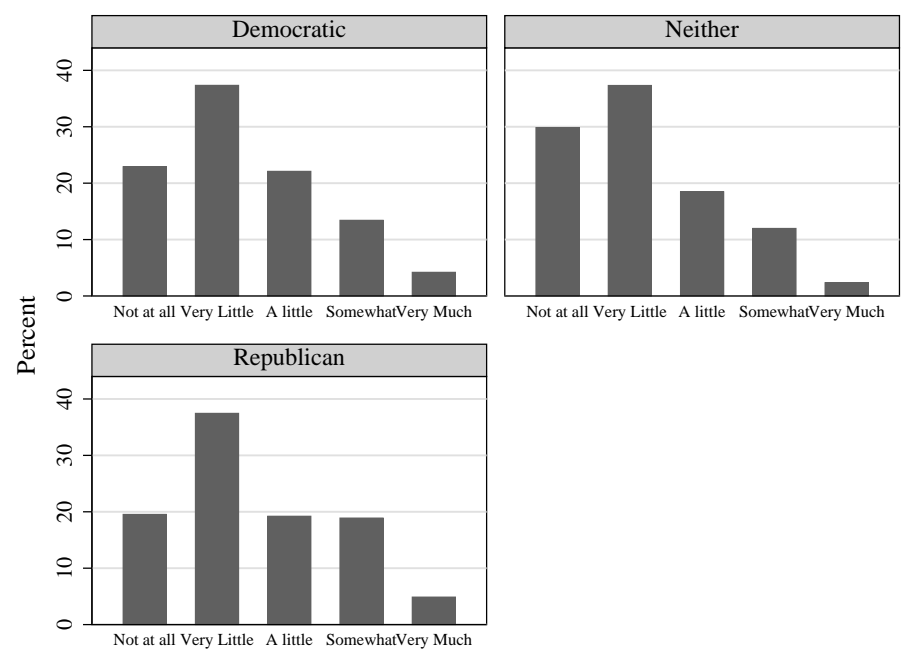

(a) Policymakers Will Consider these Findings

Policymakers Should Consider these Findings

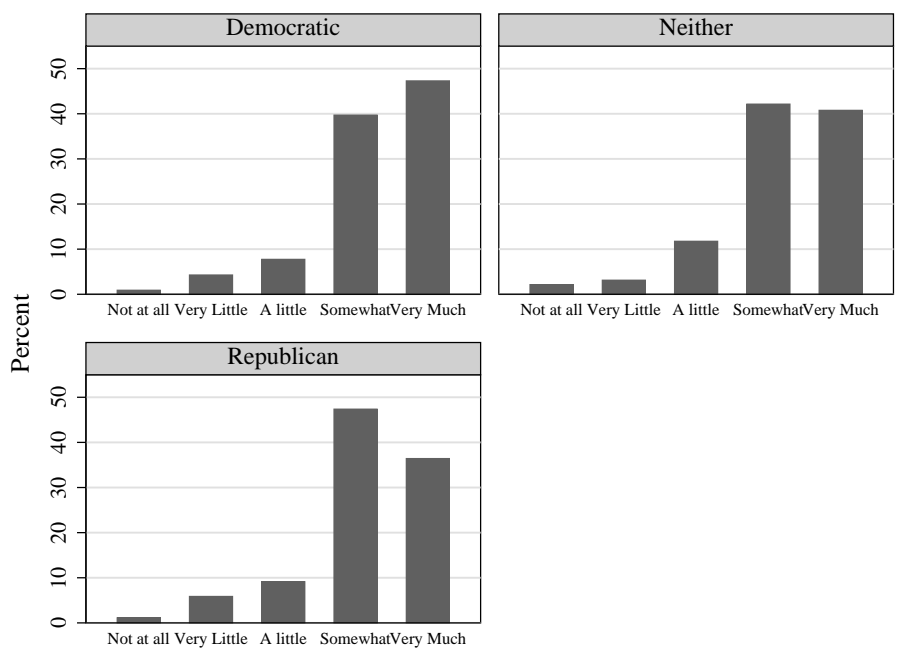

(b) Policymakers Should Consider these Findings

Figure D.3: Beliefs on the Effect of Study on Policymakers 
democratic-leaning. In addition, while there are respondents from every state, there is a mild west coast bias in the sample. Part of this is due to population: California appears most frequently but we should expect this given California is the U.S.'s most populous state. However, it is over-represented in our data (by about a 1.1 to 1 ratio). States such as Oregon (1.77 to 1 ) and Nevada (1.47 to 1 ) are also over-represented relative to their population. We suspect that this pattern partly arises because we began gathering our data late in the evening on September 7th, 2018. We expected the data gathering process to take 24 to 48 hours and, therefore, the starting time to matter little to the composition of our sample. To our surprise, the data gathering process took just under 12 hours. For Californians, and others on the west coast, this time period was roughly $5 \mathrm{pm}$ to $5 \mathrm{am}$. For east coast mTurkers, this was $8 \mathrm{pm}$ to $8 \mathrm{am}$. Without knowing in advance how long it will take to gather a given amount of data, it is unclear when the "ideal" time to begin data collection would be. State-level controls (as included most of the specifications in Table 1 of the paper) minimizes the potential for these kinds of imbalances to matter. For a complete breakdown of the geographic representation of our respondents relative to the U.S. as a whole, see Figure D.2.

\section{D.6 Characteristics of Switchers and non-Switchers}

Table D.3 lays out the demographic characteristics of the sample for those who always chose System A, those who switched, and those who always chose System B. It is comparable to Table D.2, which lays out the demographic characteristics of the sample by political affiliation. The first thing to notice is that the division into the three categories "compresses" the data. That is, relative to the differences as a function of political affiliation, the differences observed across the groups as a function of their choices, is "smaller." For example, the self-rated political "score" (on a scale of 1 to 5, where 1 is most liberal) was 1.9 for Democrats and 4.0 for Republicans in Table D.3. In contrast, these numbers are 2.4 for those who always choose System A and 3.2 for those who always choose System B.

A notable exception to that pattern is in labor market experience. Those who always chose System B tend to report earning more income and have less experience with minimum wage jobs. It is true that those who chose System B are more likely to report a religious affiliation the 
difference between the groups is less pronounced than the difference across political affiliation. A similar pattern applies to self-reported race. 
Table D.2: Selected Demographic Characteristics of Experiment Participants

\begin{tabular}{|c|c|c|c|c|c|}
\hline & & Democratic & Republican & Neither & All \\
\hline Count & & 1,095 & 614 & 510 & 2,219 \\
\hline \multirow[t]{6}{*}{ Demographics } & Age & 36.2 & 39.3 & 35.8 & 36.9 \\
\hline & Std. Dev. & 11.4 & 12.8 & 11.1 & 11.8 \\
\hline & $\%$ Male & $45.2 \%$ & $52.1 \%$ & $51.1 \%$ & $48.5 \%$ \\
\hline & White & $71.8 \%$ & $87.0 \%$ & $68.6 \%$ & $75.3 \%$ \\
\hline & Black & $12.9 \%$ & $3.1 \%$ & $10.8 \%$ & $9.7 \%$ \\
\hline & Other & $15.3 \%$ & $9.9 \%$ & $20.6 \%$ & $15.1 \%$ \\
\hline \multirow[t]{2}{*}{ Politics } & Liberal-Conservative Scale & 1.9 & 4.0 & 2.8 & 2.7 \\
\hline & & \multicolumn{4}{|c|}{ Note: $1=$ Strongly Liberal and $5=$ Strong Conservative } \\
\hline \multirow[t]{4}{*}{ Self-Reported Income } & $<\$ 20,000$ & $11.3 \%$ & $10.4 \%$ & $17.0 \%$ & $12.3 \%$ \\
\hline & $\$ 20,000$ to $\$ 60,000$ & $50.5 \%$ & $45.5 \%$ & $49.2 \%$ & $48.8 \%$ \\
\hline & $\$ 60,000$ to $\$ 100,000$ & $25.3 \%$ & $27.0 \%$ & $24.4 \%$ & $25.6 \%$ \\
\hline & $\$ 100,000$ or more & $12.9 \%$ & $17.0 \%$ & $9.4 \%$ & $13.3 \%$ \\
\hline \multirow[t]{4}{*}{ Education } & Less than High School & $0.5 \%$ & $0.2 \%$ & $0.8 \%$ & $0.5 \%$ \\
\hline & High School or Some College & $41.6 \%$ & $44.0 \%$ & $52.55 \%$ & $44.8 \%$ \\
\hline & Bachelor's Degree & $41.6 \%$ & $38.6 \%$ & $34.3 \%$ & $39.1 \%$ \\
\hline & Graduate Degree & $16.4 \%$ & $17.3 \%$ & $12.4 \%$ & $15.7 \%$ \\
\hline \multirow[t]{3}{*}{ Religion } & Christian & $39.3 \%$ & $75.4 \%$ & $36.3 \%$ & $48.6 \%$ \\
\hline & Other & $8.9 \%$ & $3.4 \%$ & $9.2 \%$ & $7.8 \%$ \\
\hline & Atheist/Agnostic/No Affiliation & $51.9 \%$ & $21.2 \%$ & $54.5 \%$ & $43.7 \%$ \\
\hline \multirow[t]{5}{*}{ Morality Questions } & Some Values are Sacred & 4.4 & 4.3 & 4.4 & 4.4 \\
\hline & Suffering for a Principle is Wrong & 3.9 & 3.5 & 3.7 & 3.7 \\
\hline & Freedom from Interference & 3.5 & 3.4 & 3.6 & 3.5 \\
\hline & Vaccine Injection & 3.5 & 3.5 & 3.4 & 3.5 \\
\hline & & \multicolumn{4}{|c|}{ Note: $1=$ Strongly Disagree and $5=$ Strongly Agree } \\
\hline \multirow[t]{3}{*}{ Min Wage Experience } & Currently Works for Min Wage & $7.5 \%$ & $5.9 \%$ & $14.0 \%$ & $8.9 \%$ \\
\hline & Ever Worked for Min Wage & $70.8 \%$ & $69.8 \%$ & $65.6 \%$ & $69.1 \%$ \\
\hline & Never Worked for Min Wage & $21.7 \%$ & $24.3 \%$ & $20.4 \%$ & $22.0 \%$ \\
\hline \multirow[t]{2}{*}{ Location } & Number of States (incl PR and DC) & 51 & 48 & 49 & 52 \\
\hline & Most Common & California $(13.3 \%)$ & California $(11.6 \%)$ & California $(14.9 \%)$ & California (13.2\%) \\
\hline \multirow[t]{2}{*}{ Repugnance } & Average for System A & 26.8 & 32.2 & 31.3 & 29.3 \\
\hline & Average for System B & 80.3 & 59.5 & 69.6 & 72.1 \\
\hline
\end{tabular}

Note: Data refers to 2,219 valid responses. See Appendix B for more on what is considered a valid response. 
Table D.3: Selected Demographic Characteristics of Experiment Participants

\begin{tabular}{|c|c|c|c|c|c|}
\hline & & Always A & Switcher & Always B & All \\
\hline Count & & 921 & 696 & 602 & 2,219 \\
\hline \multirow[t]{6}{*}{ Demographics } & Age & 37.6 & 35.7 & 37.4 & 36.9 \\
\hline & Std. Dev. & 12.1 & 11.3 & 11.7 & 11.8 \\
\hline & $\%$ Male & $49.6 \%$ & $45.5 \%$ & $50.2 \%$ & $48.5 \%$ \\
\hline & White & $78.6 \%$ & $72.4 \%$ & $73.4 \%$ & $75.3 \%$ \\
\hline & Black & $8.6 \%$ & $11.8 \%$ & $9.0 \%$ & $9.7 \%$ \\
\hline & Other & $12.8 \%$ & $15.8 \%$ & $17.6 \%$ & $15.0 \%$ \\
\hline \multirow[t]{2}{*}{ Politics } & Liberal-Conservative Scale & 2.4 & 2.8 & 3.2 & 2.7 \\
\hline & & \multicolumn{4}{|c|}{ Note: $1=$ Strongly Liberal and $5=$ Strong Conservative } \\
\hline \multirow[t]{4}{*}{ Self-Reported Income } & $<\$ 20,000$ & $13.5 \%$ & $12.8 \%$ & $10.0 \%$ & $12.3 \%$ \\
\hline & $\$ 20,000$ to $\$ 60,000$ & $49.8 \%$ & $49.6 \%$ & $46.4 \%$ & $48.8 \%$ \\
\hline & $\$ 60,000$ to $\$ 100,000$ & $25.9 \%$ & $25.3 \%$ & $25.3 \%$ & $25.6 \%$ \\
\hline & $\$ 100,000$ or more & $10.8 \%$ & $12.4 \%$ & $18.2 \%$ & $13.3 \%$ \\
\hline \multirow[t]{4}{*}{ Education } & Less than High School & $0.3 \%$ & $0.6 \%$ & $0.5 \%$ & $0.5 \%$ \\
\hline & High School or Some College & $43.2 \%$ & $46.8 \%$ & $44.7 \%$ & $44.8 \%$ \\
\hline & Bachelor's Degree & $40.3 \%$ & $37.6 \%$ & $39.0 \%$ & $39.1 \%$ \\
\hline & Graduate Degree & $16.2 \%$ & $14.9 \%$ & $15.7 \%$ & $15.7 \%$ \\
\hline \multirow[t]{3}{*}{ Religion } & Christian & $43.5 \%$ & $50.3 \%$ & $54.3 \%$ & $48.6 \%$ \\
\hline & Other & $6.3 \%$ & $8.5 \%$ & $8.1 \%$ & $7.8 \%$ \\
\hline & Atheist/Agnostic/No Affiliation & $50.2 \%$ & $41.2 \%$ & $37.6 \%$ & $43.7 \%$ \\
\hline \multirow[t]{5}{*}{ Morality Questions } & Some Values are Sacred & 4.5 & 4.4 & 4.3 & 4.4 \\
\hline & Suffering for a Ethical Principle is Wrong & 3.8 & 3.8 & 3.5 & 3.7 \\
\hline & Freedom from Interference & 3.6 & 3.4 & 3.5 & 3.5 \\
\hline & Vaccine Injection & 3.4 & 3.5 & 3.5 & 3.5 \\
\hline & & \multicolumn{4}{|c|}{ Note: $1=$ Strongly Disagree and $5=$ Strongly Agree } \\
\hline \multirow[t]{3}{*}{ Min Wage Experience } & Currently Works for Min Wage & $11.29 \%$ & $8.05 \%$ & $6.3 \%$ & $8.9 \%$ \\
\hline & Ever Worked for Min Wage & $69.1 \%$ & $69.5 \%$ & $68.8 \%$ & $69.1 \%$ \\
\hline & Never Worked for Min Wage & $19.7 \%$ & $22.4 \%$ & $24.9 \%$ & $22.0 \%$ \\
\hline \multirow[t]{2}{*}{ Location } & Number of States (incl PR and DC) & 51 & 52 & 52 & 52 \\
\hline & Most Common & California (13.1\%) & California (13.3\%) & California (13.3\%) & California (13.2\%) \\
\hline \multirow[t]{2}{*}{ Repugnance } & Average for System A & 27.9 & 25.7 & 35.7 & 29.3 \\
\hline & Average for System B & 85.7 & 72.9 & 50.3 & 72.1 \\
\hline
\end{tabular}

Note: Data refers only to the 2,219 valid responses. See Appendix B for more on what is considered a valid response. 